\title{
CAPITAL DE LA EMOCIÓN, EMOCIONES DEL CAPITAL. CONTINUIDAD Y SUPERVIVENCIA ICONOGRÁFICA DE LOS GESTOS DE SUMISIÓN Y PRIVACIÓN DE LIBERTAD EN BLACK MIRROR
}

\section{CAPITAL OF EMOTION, EMOTIONS OF CAPITAL. CONTINUITY AND ICONOGRAPHIC SURVIVALS OF THE GESTURES OF SUBMISSION AND DEPRIVATION OF FREEDOM IN BLACK MIRROR}

\author{
IVÁN PINTOR IRANZO \\ Universitat Pompeu Fabra
}

\section{RESUMEN}

El presente artículo analiza la representación de los gestos de sumisión y privación de libertad en la serie Black Mirror. A través de un método basado en la iconología del intervalo de Aby Warburg, se observan las continuidades y variaciones iconográficas de la serie con respecto a las fuentes pictóricas y cinematográficas que sustentan la distopía. Asimismo, el texto intenta crear un modelo metodológico de aplicación de la iconología warburgiana, fundamentalmente orientada a la pintura del Renacimiento, a la ficción serial contemporánea.

Palabras clave: Pintura, Aby Warburg, Nachleben, Pathosformeln, Black Mirror, Georges Didi-Huberman, Giorgio Agamben, Gilles Deleuze, Walter Benjamin, Heidegger, Foucault, Byung Chul-han, distopía, Fumaroli, Otium, San Junipero, Nosedive.

\section{ABSTRACT}

This article analyzes the representation of political submission and deprivation of liberty gestures in the tv series Black Mirror. Throughout a method based on Aby Warburg's iconology, the article observes continuities and iconographic variations with respect to the pictorial and cinematographic sources that support the dystopia. Likewise, the text tries to create a methodological model of application of the Warburgian iconology, fundamentally oriented to Renaissance painting, to contemporary tv fiction.

Keywords: Painting, Aby Warburg, Nachleben, Pathosformeln, Black Mirror, Georges Didi-Huberman, Giorgio Agamben, Gilles Deleuze, Walter Benjamin, Heidegger, Foucault, Byung Chul-han, dystopia, Fumaroli, Otium, San Junipero, Nosedive. 


\section{RESUM}

Capital de l'emoció, emocions del capital. Continuïtat i supervivència iconogràfica dels gestos de submissió i privació de llibertat a Black Mirror

Aquest article analitza la representació dels gestos de submissió i privació de llibertat en la sèrie Black Mirror. Mitjançant una metodologia basada en la iconologia de l'interval d'Aby Warburg, observem les continuïtats i variacions iconogràfiques de la sèrie pel que fa a les fonts pictòriques i cinematogràfiques que sustenten la distòpia. Així mateix, el text intenta crear un model metodològic d'aplicació de la iconologia warburgiana, fonamentalment orientada a la pintura del Renaixement, a la ficció serial contemporània.

Paraules clau: Pintura, Aby Warburg, Nachleben, Pathosformeln, Black Mirror, Georges Didi-Huberman, Giorgio Agamben, Gilles Deleuze, Walter Benjamin, Heidegger, Foucault, Byung Chul-han, distopia, Fumaroli, Otium, Sant Junipero, Nosedive. 


\section{Una aproximación gestual}

Hubo un tiempo en que la pintura, la escultura y la plástica antigua hicieron de los gestos el espacio de una comunicación entre lo humano y el lenguaje sagrado de los dioses. Entretanto, los códigos de comunicación gestual se transmitían de generación en generación, a través de la familia, la educación y las formas compartidas de cohesión social. "No hay poema que no vaya acompañado de gesticulaciones, de una postura del cuerpo apropiada y un tratamiento musical del lenguaje; no hay acto solemne que no asuma una forma musical poética ni hay creación de las artes visuales en que no reverberen los motivos del lenguaje la música y la expresión corporal...", aseguraba Karl Lamprecht en 1905 (Gombrich, 1995: 45). La psicología social de Lamprecht (1900, 1906-11) supo atender al gran cambio que, en la pintura, supuso la irrupción del arte del retrato a partir del siglo XIV y durante los siglos posteriores, si bien fue formulada precisamente en la época en la que la fotografía y el cine estaban provocando una alteración aún más radical de las formas de representación social y de los modos de construcción de la memoria íntima y compartida.

Con los medios de comunicación de masas, con la difusión masiva del cine sobre todo, el conjunto de las sociedades humanas se vio sacudido por una fuente de creación imaginaria basada en el vigor de lo irrepetible, en la concreción de pathos fantasmales, en la fijación del moto, del gesto. Que el cine no es sólo una forma de preservación del lenguaje expresivo del gesto en movimiento sino que constituye un agente de creación y transmisión gestual es el punto de partida de cualquier aproximación que trate de inscribir las fórmulas y supervivencias iconográficas audiovisuales en una tradición más amplia, pictórica y cultural. Partiendo del texto seminal de 
Giorgio Agamben, Notas sobre el gesto (2001) y desde una propedéutica fundada en la antropología pero reorientada hacia la figuración a través de la metodología contrastante del cine y el audiovisual comparado, es posible acercarse a fenómenos como la ficción serial televisiva contemporánea para arriesgar preguntas como: ¿existen sistemas de gestos coherentes o dominantes dentro de una determinada serie? ¿Qué relaciones de continuidad y ruptura se dan entre los sistemas gestuales de la serialidad contemporánea, los del cine y los de la tradición pictórica? ¿Es posible reconocer un horizonte imaginario compartido en determinados géneros de la serialidad a partir de la articulación gestual?

El gran proyecto de creación de un camino alternativo de aproximación a la historicidad de las imágenes gestado por el historiador del arte Aby Warburg es la matriz a partir de la cual, en un sentido hermenéutico, se esbozará una propuesta a la vez metodológica y aplicada de indagación gestual en el contexto de la serie Black Mirror (Channel 4: 2011-2014; Nefflix: 2016-). En ella, el gesto aparece como mediador entre fuerzas corporales y sociales, psicológicas e históricas. Llámese iconología del intervalo - kkonologie des Zwischenraums- o, como quería el propio Warburg (1995, 1999), ciencias de la cultura, lo esencial de su legado, más activo ahora que nunca a través de filósofos y estudiosos del arte como Giorgio Agamben (2005), Georges Didi-Huberman (2002, 2009, 2010) y Philippe-Alain Michaud (1998), es la valoración prioritaria de la transmisión, la historicidad, la empatía artística - einfühlung - y el interés por una historia del arte menos atenta a períodos y autores que "a lo que sucede en el observador" a partir de la respuesta energética, emotiva, hacia los repertorios y supervivencias gestuales - nachleben-, las fórmulas de pathos - pathosformeln- que se transmiten a lo largo de la historia, escapando a los nombres, escuelas y tendencias ${ }^{1}$.

De igual modo que la propia biblioteca de Warburg, que estaba organizada en función de constelaciones de sentido, las imágenes de su atlas - Bilderatlas- Mnemosyne (1924-1929), concebido como un archivo en movimiento, están agrupadas de manera temática con la intención de suscitar un modelo de "conocimiento a través del montaje" (Pintor, 2017, 2018). Sobre los plafones que las sustentan, la articulación entre imágenes trata de hacer emerger la historicidad a través de la interferencia de los contextos

1 Véanse, asimismo, los estudios de Sabine Lenk y Frank Kessler (1996), Roberta Pearson (1992), Pasi Väliaho (2010), así como el monográfico de Journal for Cultural Research con artículos de Laura Mulvey, Nicholas Care, Barbara Creed y Elizabeth Cowie (Chare, Watkins 2015). 
de cada gesto. La distancia entre gestos es, al mismo tiempo, espacio de mediación -Zwischenraum - y Denkraum, un espacio de pensamiento activo al que es posible regresar en todo momento. En su introducción a Mnemosyne (1929), Warburg empleó ambos conceptos y, si bien el primer uso del término Denkraum en el texto Schlangenritual. Ein Reisebericht, presentado originalmente en 1923 (Warburg, 1988: 59), está relacionado con el mito y el pensamiento simbólico, el significado más usual en su trabajo posterior apunta hacia la memoria -Gedächtnis- (Cirlot, 2017), con una idea de historia fantasmagórica siempre abierta hacia nuevas reformulaciones.

La atención hacia las sacudidas temporales es lo que hace de Mnemosyne una herramienta desde la cual pensar un fenómeno como la serialidad, que al igual que el cine, constituye, de acuerdo con la expresión de Oksana Bulgakova, una "fábrica gestual" (Bulgakova, 2005, 2013: 251). A través de la posibilidad que el género de la ciencia-ficción ofrece para narrar las praxis sociales del presente, la serie televisiva Black Mirror explora -y a la vez fabrica - las fórmulas expresivas de la sumisión, la privación de libertad y la dificultad para construir una comunidad articulada y plural en la sociedad contemporánea. Seres humanos que pedalean en cubículos cubiertos de pantallas para conseguir ganar puntos que les permitan participar en un concurso o consumir bienes virtuales, ciudadanos aislados que evalúan cada interacción social con un sistema de realidad aumentada, políticos chantajeados o convertidos en un monigote virtual y conciencias póstumas transferidas a la red o a pequeños gadgets portátiles configuran una galería iconográfica de los gestos de la distopía en la que resulta difícil encontrar verdaderas fórmulas de pathos - Pathosformeln - entendidas en el sentido que les concediera Warburg, como confrontación con la pasión, la adversidad, el sufrimiento o, en última instancia, la finitud y la muerte.

Aunque Warburg nunca definió la expresión pathosformeln, que hilvana la idea de la transmisión estable - fórmula - con la del desequilibrio, la inestabilidad y la transitividad de la emoción — pathos, má $\theta$ os_, es posible distinguir en el uso que hizo de este concepto al estudiar la iconografía pictórica del Renacimiento (Warburg 1999) la manifestación del sufrimiento provocada por el encuentro con el dolor, la negatividad o la irrupción de la alteridad. En tanto que los diferentes capítulos de Black Mirror configuran un auténtico atlas visual de la confrontación entre libertad individual y tecnología, progreso y retorno a formas de animalidad en las que la vida es sustituida por la pura supervivencia, cabe preguntarse en qué gestos, a través de qué formas concretas cristaliza esta oposición en el contexto de un universo del que ha sido extirpada la idea de negatividad -entendida, con Heidegger, en tanto Nichtheit, como vector trágico del tiempo y con- 
dición esencial del $\operatorname{ser}^{2}-$ y del que el otro, la alteridad, ha desaparecido. Así pues, si la verdadera potencia del pathosformeln estriba, precisamente, en el choque con el otro y la circulación de la emoción hacia el otro. ¿ Con qué imágenes, qué gestos o qué ausencias gestuales codifica Black Mirror la representación de la coerción de las libertades individuales?

\section{LA CONSTRUCCIÓN DEL PATHOSFORMELN}

Que los gestos tienen tanto de acción como de reacción dependiendo de su naturaleza es algo que la historia de la pintura no ha dejado de explorar, a menudo en una constante dialéctica con su función social. Como Wilhelm Wundt (1912) y Chastel han señalado, el pintor cuenta con la condición figsionómica y gestual como una gran contingente de recursos afín al de la perspectiva:

la composición pictórica no deja de ser una forma simbólica. Los gestos expresivos son uno de los dos grandes medios que el pintor tiene a su disposición para suscitar reacciones comparables a las de lo vivido. Al lado de la perspectiva (...), debemos considerar el efecto figsionómico, en lo esencial fundado en los gestos, como una segunda perspectiva, una perspectiva psíquica, psicofisiológica, si se quiere (Chastel, 2004: 22-23).

Sin embargo, desde el punto de vista de la tradición instaurada por Warburg, sería una limitación contemplar la construcción gestual en la pintura como un simple recurso al servicio de la consecución de una imagen, esto es una forma cerrada, estabilizada, desde la cual representar un proceso empático sustraído al flujo de la historia.

Por el contrario, es la movilidad energética lo que Aby Warburg introduce en su aproximación a la cultura fundada en una ciencia histórica del gesto,

2 Partiendo de una relectura crítica de Hegel, así como de la fenomenología, Heidegger señala en Ser y tiempo (1927) § 82: "Por eso Hegel puede determinar apofántico-formalmente la esencia del espíritu como negación de la negación. Esta 'absoluta negatividad' ofrece la interpretación lógicamente formalizada del cogito me cogitare rem de Descartes, en el que éste ve la esencia de la conscientia". Y añade: "El tiempo es la negatividad 'abstracta'. En cuanto 'devenir intuido', el tiempo (435) es el diferenciarse diferenciado que se encuentra inmediatamente allí, el concepto 'existente', es decir, el concepto que está-ahí. Estando-ahí y, por tanto, siendo externo al espíritu, el tiempo no tiene ningún poder sobre el concepto, sino que el concepto 'es, más bien, el poder del tiempo'". 
tal y como Agamben ha subrayado en el mencionado texto "Notas sobre el gesto": "En esos mismos años Aby Warburg da los primeros pasos en un tipo de búsquedas a las que sólo la miopía de una historia del arte psicologizante pudo definir como 'ciencia de la imagen', mientras que en rigor su verdadero centro era el gesto como cristal de memoria histórica, convertida su rigidez en destino, junto al incansable empeño de artistas y filósofos (que para Warburg lindaba con la locura) por liberarle de ello mediante una polarización dinámica" (Agamben, 2001: 51). Es precisamente porque allí donde otros veían formas delimitadas, Warburg era capaz de percibir las grandes energías configurantes - die grossen gestaltenden Energien-, tal como señaló el padre de la antropología filosófica Ernst Cassirer en su elogio fúnebre (Didi-Huberman, 2002: 200), por lo que su concepción del pathosformeln aparece, desde el principio, imbuida por la idea del dolor y la violencia asociada a la fuerza vital -lebenskräftig- de su implantación.

La tonalidad afectiva, el stimmung ${ }^{3}$ que acompaña la energía pática ${ }^{4}$ del gesto comparece, pues, bajo la idea dominante de la exposición del dolor, como ha subrayado Georges Didi-Huberman tanto al vincular algunos de los lineamientos warburgianos con El nacimiento de la Tragedia (1872), de Friedrich Nietzsche (Didi-Huberman, 2002: 142), como, al desarrollar la idea de la representación de la colectividad en Peuples exposés, peuples figurants. L'Oeil de l'Histoire, 4 (2012) y Peuples en Armes, Peuples en Larmes. L'Oeil de l'Histoire, 6 (2016). La emoción, sostiene a partir de Warburg, 5 nunca afirma un "yo", sino que siempre apela a un tú. En el acto afirmativo de dejar aparecer el afecto o el dolor, la representación de la emoción a través de su dimensión gestual siempre apela al "tú", y traspone algo de su aparente impotencia. Lo que Didi-Huberman señala al

3 Que se recupera, además, en el sentido con el que Agamben $(1980,1982)$ ha definido este concepto a partir de Sein und Zeit (1927), de Martin Heidegger, y de la lectura de la poesía de Hölderlin. Además de subrayar su naturaleza de "tonalidad emotiva" del stimmung, Agamben subraya su naturaleza liminal: el stimmung no corresponde ni a la interioridad de ser, el Dasein, ni al mundo, sino al límite entre uno y otro, a la apertura del Dasein al mundo

4 El adjetivo "pático", empleado por vez primera por el psicólogo fenomenólogo Erwin Strauss, fue recogido, sobre todo, por Viktor von Weizsäcker en los años treinta y acabó dando pie a su atención hacia lo que denominó Patosofía (Viktor von Weizsäcker, Patosofía. Traducción de Dorrit Bush Buenos Aires: Editorial Libros del Zorzal, 2005).

5 Véase, en particular: El renacimiento del paganismo. Aportaciones a la historia cultural del Renacimiento europeo (Warburg, 2005), y también: L'Image survlvánte. Histoire de l'art et temps des fantômes selon Aby Warburg (Didi-Huberman, 2002). 
prolongar cuanto Warburg supo tomar de las investigaciones de Charles Darwin en The Expression of the Emotions in Man and Animals (1872) y de autores como el antropólogo italiano Paolo Mantegazza (1874, 1876, 1880, 1881), -tal como han señalado Jessica Murano (2016: 169) y Victoria Cirlot (2019) - es que la exposición de la carencia nunca comporta impotencia o pasividad sino una apertura que prácticamente comporta lo contrario.

La evidencia fenomenológica de la expresión emocional, que tiene su extremo en el llanto, en el dolor, pero que recoge un sinfín de matices afectivos, supone también la posibilidad de reencontrar el rostro en un sentido profundo y de mostrarse en plenitud. Resulta sustantiva, en ese sentido, la noción de privilegio - Vorrecht- empleada por Georg Wilhelm Friedrich Hegel cuando habla del "privilegio del dolor" (1970: 321) como patrimonio de la condición humana. Desde ese "privilegio del dolor", argumenta Georges Didi-Huberman, el individuo adquiere la posibilidad de conectar con aquello que Friedrich Nietzsche (1977: 321), por su parte, denominara "la fuente originaria" - Urquell-. Quizá lo que, sobre todo a través de sus aproximaciones a Eisenstein, cristaliza en el estudio de Didi-Huberman es que la exposición gestual de la pasión en la tradición pictórica y fotográfica puede ser contemplada como acción, algo ya intuido y manifestado por Maurice Merleau Ponty (1945) desde la fenomenología, o por Henri Bergson y Gilles Deleuze (1968, 1981) desde la filosofía: la emoción, de acuerdo con ellos, es movimiento, apertura y potencia.

Esto es, desde el análisis del gesto no es posible sostener la interpretación tradicional de la tabla categorial de Aristóteles según la cual el pathos, a diferencia del logos, está privado de acción y voluntad. Tampoco puede serlo desde un análisis atento a la materialidad expresiva de los rostros, gestos y "puesta en gestualidad" de la escena cinematográfica. El gesto máximo de impotencia, la exposición de la pasión que abate o somete, conduce, paradójicamente, a su opuesto, al límite de la acción. Al fin y al cabo, como Freud ha indicado, "el deseo es indestructible", y con él la emoción y la carencia que es mostrada. En el trabajo sobre la relación entre el gesto pintado y sus proyecciones antropológicas emerge la certeza de que nuestra conciencia es esencialmente emocional, como Judith Butler, a partir del trabajo de Karl Jaspers (1928) y de Jean-Paul Sartre (1938), ha señalado a lo largo de sus obras. La cuestión fundamental es, por cuanto ocupa a la presente investigación ¿̇Cómo se transmiten y dialogan los gestos de dominación y agresión con los de privación de liberad, reclusión y sumisión? ¿̇En qué medida está presente el "tú" del espectador en la construcción gestual de una serie como Black Mirror? ¿ ¿ómo se inscriben esos gestos en la tradición? 
Un primer gesto, prácticamente tan antiguo como las grandes formas de civilización ulteriores al neolítico, puede transcribir cómo la plástica ha codificado los gestos de dominación, de poder, imposición y violencia desde el punto de vista del vencedor. La Paleta de Narmer (3050 aC), una placa ceremonial de esquisto tallada con bajorrelieves que se conserva en el Museo Egipcio de El Cairo, es el documento con el que se considera que comienza el Egipto dinástico de los faraones. En su anverso, la unificación del Alto y el Bajo Egipto surgida de la victoria del primero aparece encarnada en el gesto de agresión con el que el rey Narmer, con la corona blanca del Alto Egipto, golpea a un extranjero con cabello rizado y barba, caracterización habitualmente empleada para identificar a los libios y asiáticos, pero en este caso muy probablemente asociada a los habitantes del delta occidental. Más allá de la presencia de las divinidades Horus y Hathor, o de los símbolos que en el anverso encarnan la unidad de Alto y Bajo Egipto, interesa el gesto concreto de Narmer agarrando con la mano izquierda el cabello de su enemigo, que aparece postrado y alzando hacia atrás con la diestra el mazo a punto de golpear. ${ }^{6}$

\section{Dominación e insurrección: de la paleta de Narmer a Black Mirror}

Ese gesto se transmitió a lo largo de toda la historia del Egipto Antiguo, incluso en el caso de faraones de los que no queda clara su intervención real en ninguna batalla - así aparecen, entre otros, Tutmosis III en Karnak, Ramsés II en Abu Simbel, Ramsés III en Medinet Habu o Ptolomeo XII en Edfu-. Pervivió, a lo largo de las representaciones de la cuenca del Mediterráneo, al encarnarse en instantes de lucha, dominación y sometimiento diversos, desde la lucha entre lapitas y centauros recogida por el friso del altar de Pérgamo (197-159 aC) hasta la imagen canónica de Teseo abatiendo al Centauro de Canova (1805-19), pasando por frescos como La muerte de Penteo en Pompeya (Casa de los Vettii, $-62 \mathrm{dC}$ ) o trabajos como La muerte de Orfeo de Albrecht Dürer (1494), así como el conjunto de toda la iconografía con la que durante el siglo XX han sido representadas las formas de represión policial y militar. Lo interesante es pensar cómo a la energía agresiva que causa la sumisión corresponde una energía pática igual o

6 Aluda a una batalla por el control del Delta, como señala Gardiner (Shaw, Nicholson, 1995: 197) o bien a una mera encarnación simbólica del poder del faraón (Baines, 1989), lo importante es justamente cómo ese gesto es mediador entre la realidad de la guerra y la dimensión simbólica y, en muchos sentidos, mitológica y teológica que sustenta el poder real en el instante del primer registro dinástico del Egipto unido. 
mayor, que es la que acompaña al sometido a través de la participación del observador fomentada por los pathosformeln.

La expresión corporal y anímica intensificada - gesteigerten körperlich oder seelischen Ausdrucks- de esas imágenes observa una natural continuidad con cuantas formas de la represión han sido planteadas en un género tan poco cultivado por la pintura antes del siglo XX como central para entender el desarrollo del cine y la televisión contemporánea: el de las formas de la distopía que, con un claro origen en la literatura de ciencia ficción, han sabido recoger los códigos representativos de saqueos, raptos, flagelaciones y representaciones de la esclavitud que la pintura había cultivado previamente. Películas tan diversas como Metrópolis (Fritz Lang, 1927), La naranja mecánica (A Clockwork Orange, Stanley Kubrick 1971), Mad Max (George Miller, 1979) o 1984 (Michael Radford, 1984), así como largometrajes del ámbito extremo-oriental como Battle Royale (Kinji Fukasaku 2000) son capaces de acoger gestos de naturaleza política como el mencionado con la misma intensidad con la que un cineasta militante como Peter Watkins ha sabido, asimismo, hacerlo en filmes como Punishment Park (1971).

Sin embargo, existe un cauce a menudo difícil de analizar dentro del espacio representativo de la ciencia ficción cinematográfica y televisiva que es el de la presentación de la distopía desde códigos iconográficos de un falso bienestar que deben más a la lógica y la tradición del otium grecolatino -cuya supervivencia ha sido extraordinariamente estudiada por Marc Fumaroli $(2008,2010)$, así como en la magnífica exposición Otium Ludens. Ancient Frescoes of Stabiae (Hermitage, 2007) - . Obligados a vivir en un mundo luminoso, los personajes de este tipo de ficciones sufren un engaño o aceptan a través del consenso su dominación. Su pathos se identifica con el gesto, perplejo, que lleva al protagonista de El show de Truman (1998), de Peter Weir, a descubrir a plena luz un decorado donde presumía un horizonte, un ademán de tocar -tocar el decorado, manipular el software - repetido en un conjunto de películas coetáneas y afines: ¡Están Vivos! (John Carpenter, 1988), Desafío total (Total Recall, Paul Verhoeven, 1990), Strange Days (Kathryn Bigelow, 1995), The Game (David Fincher, 1997), Abre los ojos (Alejandro Amenábar, 1997), eXistenZ (David Cronenberg, 1998), e incluso las ulteriores Paycheck (John Woo, 2003), Una mirada en la oscuridad (A Scanner Darkly, Richard Linklater, 2006), u Origen (Inception, Christopher Nolan, 2010).

7 Véase: Guzzo, P.G. y Bonifacio, G. (ed.). Otium Ludens. Stabiae, cuore de l'impero romano (2009). 


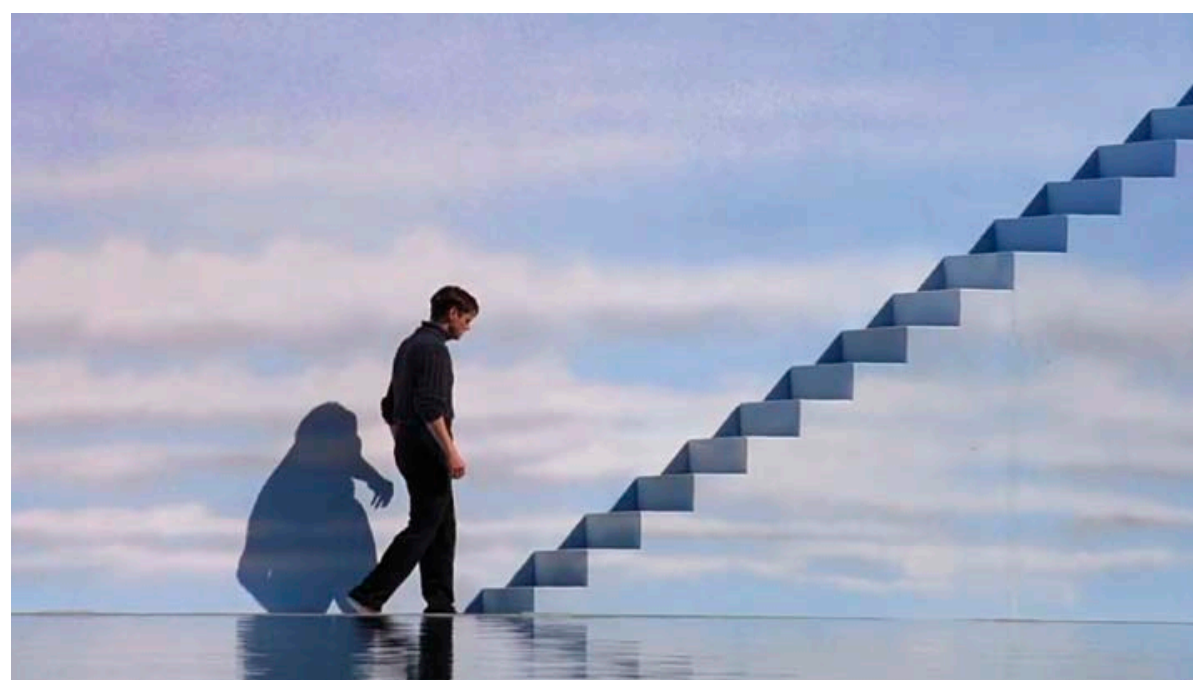

Fig.- 1. El show de Truman (The Truman Show, 1998).

Todos esos largometrajes abundan en la idea de una falsa apariencia líquida, un software mental destinado a encubrir una conspiración o bien a engañar al individuo para ocultarle el abismo de lo real sobre el que se fragua su propia explotación. Este modelo de fantasía paranoica ha sido analizado en otros textos bajo el signo de la acedia, uno de los pecados o vicios capitales que distinguían los padres de la iglesia y cuya cohorte infernal de síntomas se identifican con lo que Heidegger denominó la banalidad cotidiana (Pintor, 2009, 2012). A menudo, la puesta en gestos y la puesta en escena que acompaña a este cauce representativo vienen dados, precisamente por una erosión o inhibición de gestos específicos de violencia o de manifiesta sumisión, pues el interés estriba en exhibir la posibilidad de que ciertas tecnologías priven de libertad sin que ello resulte visible de modo manifiesto. Sobre un esquema de (in)habitabilidad, que halla en la noción de esfera del filósofo alemán Peter Sloterdijk (1998-2004) su mejor definición y en los panales en los que dormitan los humanos en Matrix (1999), de los hermanos Wachowsky, su imagen más certera, se fragua la obsesión borgiana y estéril de Cotard, el protagonista de Synechdoche, New York (2008), de Charlie Kaufman, por transcribir su experiencia en una maqueta.

Esa idea de una realidad-maqueta es, precisamente, el punto de partida de Black Mirror. Si bien muchos de los capítulos cristalizan en un "moto", esto es un gesto que no es tan sólo caracterización sino confrontación dinámica con la opacidad del sufrimiento del personaje - de acuerdo con el 
término acuñado por Giorgio Vasari- que constituye una reacción contra las praxis de dominación, todo hasta ese instante está constituido por una sucesión de gestos banales concebidos como puros cenni ${ }^{8}$ o signa membrorum de la normalidad cuando no paródicos de una opulenta sociedad del bienestar consumista. La negatividad que atraviesa películas como Alphaville (Jean-Luc Godard, 1965), Farenheit 451 (François Truffaut, 1966), -adaptación del relato homónimo de Ray Bradbury-, THX 1138 (Georges Lucas, 1971), Soylent Green (Richard Fleischer, 1973), A Boy and His Dog (L. Q, Jones, 1975), Brave New World (Burt Brinckerhoff, 1980) y 1984 (Michael Radford, 1984), basadas respectivamente en las novelas de Georges Orwell y Aldous Huxley, así como clásicos del cyberpunk occidental y oriental en un sentido amplio, como Blade Runner (Ridley Scott 1982), Akira (Katsuhiro Otomo, 1988) y Ghost in the Shell (Mamoru Oshii, 1995), parece siempre haber desaparecido de la mayor parte del metraje de cada uno de los capítulos de Black Mirror.

Así pues, la vida en movimiento - bewegter Lebensschilderung- de los gestos de Black Mirror comparece bajo un tensionamiento que contrae la energía de los pathosformeln de sumisión, esos a los que escritores como el alemán Peter Weiss habían consagrado su atención para retratar el destino político del siglo XX.9 Como se ha explicado en otro lugar (Pintor, 2018), la pobreza de negatividad en las sociedades post-capitalistas contemporáneas, contra la que la serialidad contemporánea responde a través de la representación del mal -True Detective (HBO: 2014-2015), Hannibal (NBC: 2013-2015), The Jinx (HBO: 2015)-, la violencia - Los Soprano (The Sopranos, HBO: 1999-2007), Breaking Bad (AMC: 2008-2013), Juego de Tronos (Game of Thrones, HBO, 201 1-)- o la codificación abstracta del vacío - Twin Peaks, The Return (Showtime: 2017)- aparece expuesta tal cual en Black Mirror y ahí radica, especialmente, su identidad como

8 De acuerdo con la terminología empleada en L'arte de' cenni, de Giovanni Bonifacio (1616), vinculado a la tradición retórica de Quintiliano en la cual se inspiró Wilhelm Wundt para su Völkerpsychologie (1912).

9 "A nuestro alrededor se alzaban los cuerpos surgiendo de la piedra en grupos compactos, entrelazados unos con otros o desgajándose en fragmentos, con un torso, un brazo apoyado, una cadera quebrada, un fragmento rugoso insinuando su forma original, siempre los ademanes de la lucha". Con la larguísima descripción de la gigantomaquia del mencionado friso del altar de Pérgamo, La estética de la resistencia abre un recorrido por la vida -lebende las imágenes europeas desde la Guerra Civil española y a través de los grandes conflictos y transformaciones de la lucha del proletariado por sus derechos. 
serie. Por una parte, se produce una profunda comunión iconográfica con las fantasías de ciencia ficción basadas en la idea de maqueta y falsedad de las apariencias durante los años noventa, antes de que el $11-S$ tiñese de una flagrante negatividad la ficción popular de origen anglosajón y, por otra, dicha negatividad queda en un segundo plano que en ocasiones cristaliza a través de un gesto contundente pero puntual de rebelión o desesperación al final de cada capítulo.

\section{JUSt DO IT: SOBRE El IMPERATIVO dE LA POSITIVIDAD}

De igual modo que buena parte de los relatos de Black Mirror, el capítulo Nosedive (\#3x01, 2016), escrito por Charlie Brooker y adaptado para televisión por Rashida Jones y Michael Schur, transcurre en un mundo de ficción especulativa no demasiado diferente a la realidad contemporánea. Gracias a unos implantes oculares conectados con el teléfono celular, todas las actividades diarias de la población son compartidas, y cada interacción social es valorada mediante una escala de una a cinco estrellas en un ranking público que aparece, mediante una app de realidad aumentada, al lado de cada persona, algo que hace pocos años proponía la app Pee$p e^{10}$. La fantasía paranoica de una realidad-simulacro, que tiene su origen en relatos de Philip K. Dick como Time Out of Joint (1959) no requiere, en el mundo contemporáneo, especular con la necesidad de ocultar a la población que su vida es una mentira, como sucedía en series como El prisionero (The Prisoner, 1967-68), Dr. Who (1963-1989), The Twilight Zone ${ }^{11}$ e incluso algunos capítulos de Alias (ABC: 2001-2006). Esa mentira se asume de manera natural como interfaz social ${ }^{12}$, y el objetivo de la protagonista, Lacie Pound (Bryce Dallas Howard), que goza de una calificación de 4,2, es ascender a 4,5 con el fin de obtener un descuento para adquirir un apartamento de lujo.

Como en una pesadilla surgida de las películas protagonizadas por Doris Day a finales de los años cincuenta, los tonos pastel, salmón, rosa y azul se adueñan de oficinas, rebecas y batidos que todo el mundo se ofrece con

10 Conocida como el Yelp de las personas, Peeple se presentó en 2015. Creada por Julia Cordray y Nicole McCullough, posibilita que unos usuarios valoren a otros con un sistema de estrellas.

11 En episodios como A World of Difference (1960), dirigido por Ted Post, o Monsters on Maple Street (1960), que explora las mecánicas excluyentes de los suburbios estadounidenses.

12 Como también ha explorado una serie contemporáneas como Community (NBC-Yahoo!, 20092015) el episodio App Development and Condiments (\#5x08, 2014), escrito por Jordan Blum y Parker Deay y dirigido por Rob Schrab. 
cordialidad en oficinas de atmósfera balsámica y urbanizaciones de casas idénticas con jardín. La sonrisa indeleble en los labios de Lacie, como un rictus siniestro de contención, parece cobijar una sombra funesta a punto de emerger. Pero a diferencia del acercamiento a una sociedad en la que la persistencia del modelo representativo del american dream de los años cincuenta custodia la inquietante amenaza de lo no visto, como sucede con Twin Peaks, largometrajes de David Lynch como Mulholland Drive (2001) o incluso la serie Mad Men (AMC: 2007-2015), la verdadera pesadilla de Nosedive es que no aflora una negatividad capaz de quebrar el exceso de positividad que confrontan los personajes. Con una banda sonora en la que las melodías de Max Richter se entreveran con el insistente sonido de la app de valoración, Nosedive constituye un friso de gestualidades casi surgido de las ilustraciones del pintor Norman Rockwell, tamizado con el gesto obsesivo de la calificación en la pantalla del teléfono.

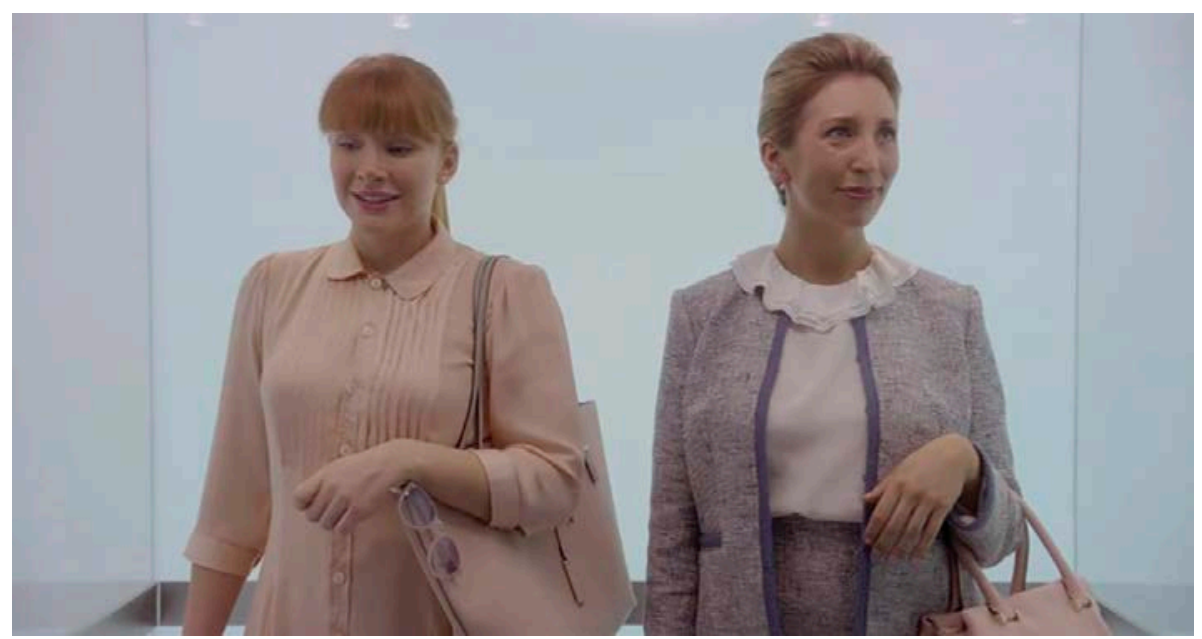

Fig.- 2. Black Mirror, Nosedive (\#3×01, 2016).

Así como una tradición pictórica tan longeva como la española siempre ha estado fundada sobre un reducto de negatividad, particularmente vinculado a la representación de la pobreza, la muerte y la caducidad del mundo material, especialmente en el Barroco, hay que tener en cuenta que, en muchos sentidos, Black Mirror, a pesar de ser una serie británica, se abreva de fuentes iconográficas estadounidenses en su representación de un sistema post-capitalista que es el sistema mundial compartido por todos los países más ricos del planeta. Quizá porque el sistema iconográfico estadounidense eclosiona de forma pareja a los medios de difusión masiva, se produce una indiscernibilidad entre los mundos del consumo y 
la publicidad y los de la pintura durante las décadas finales del siglo XIX y las iniciales del XX, de ilustradores como Frederic Remington, el gran cultor del western, hasta la pintura de Hopper y Hockney, que en tantos sentidos han encontrado en la literatura de John Updike, John Cheever y Raymond Carver su natural correlación. Es en este sentido un programa iconográfico como el que vertebra el conjunto de la obra del dibujante de cómic Chris Ware, en su proyecto Acme Novelty Library, el que mejor explica la tradición que recae sobre imágenes como las invocadas en este capítulo de Black Mirror, así como la ética que, en él, separa el triunfo de la figura del loser.

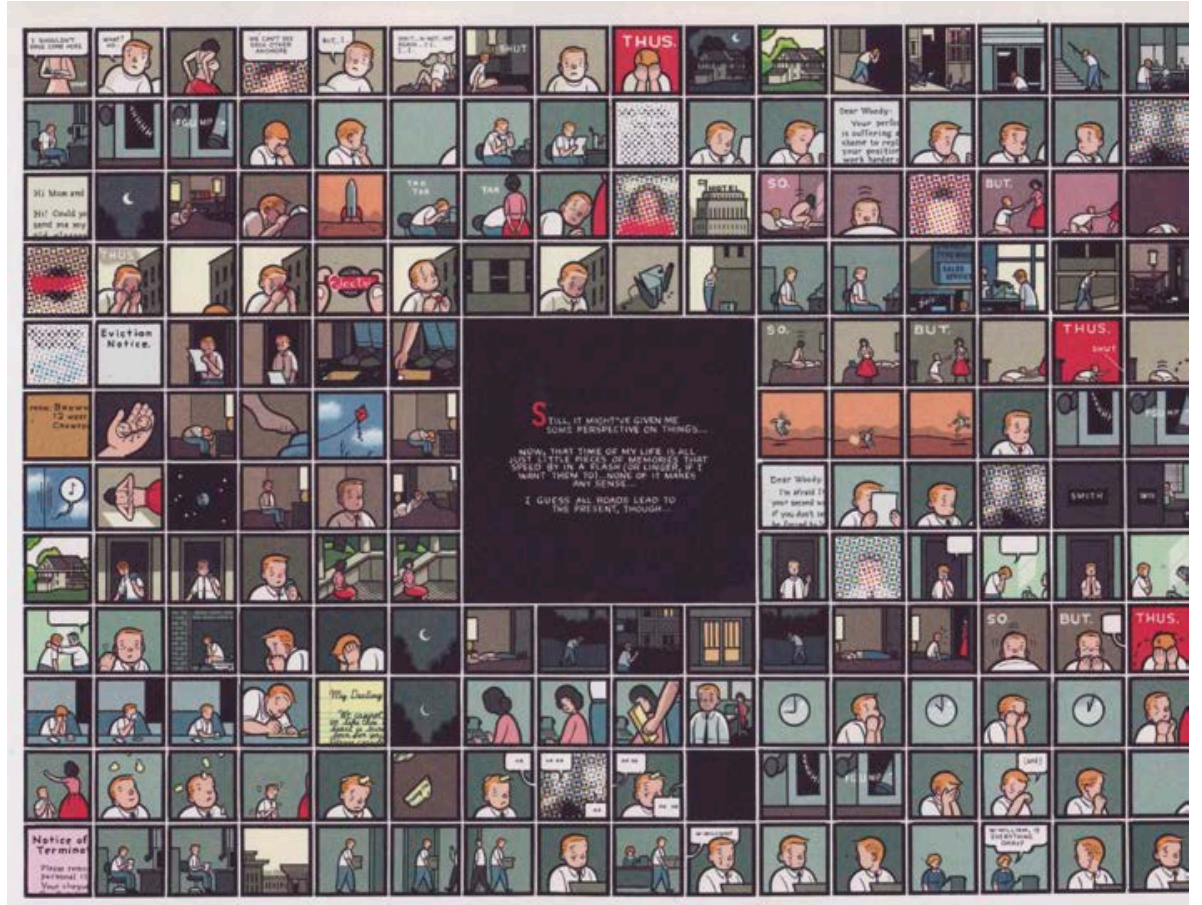

Fig.- 3. Chris Ware, The ACME Novelty Library, N²0. Drawn \& Quarterly Publications, 2010.

Relacionarse con quality people para mejorar la propia cotización, la recomendación que un consultor realiza a Lacie y que le hace rehuir el encuentro con cualquiera por debajo de su ranking, es el mandato que preside las interacciones sociales en el universo narrativo de Nosedive, una prolongación del concepto de "popularidad" asociado a los relatos adolescentes es- 
tadounidenses, así como del fenómeno pseudo-religioso de las celebrities. "La desaparición de la otredad significa que vivimos en un tiempo pobre de negatividad", señala el filósofo Byung Chul-han (2012: 17), al referirse a las sociedades contemporáneas configuradas por el uso de las redes sociales. La naturaleza expansiva y omnímoda de una positividad que anula el discurso aparece, además, asociada a lo que el filósofo Jean Baudrillard denomina "la violencia del consenso" (2006: 46), pues es el consenso social lo que sustenta la creación de un sistema de anulación de las libertades en casi todo el arco de distopías presentadas por Black Mirror. Asimismo, es el consentimiento personal con el que el individuo acepta y se somete al imperativo tecno-ideológico (Chomsky, Herman, 1988) lo que anula en torno él una construcción relacional con el resto de individuos abierta a la diferencia y capaz de sustentar un verdadero espacio político en el sentido en el que lo entendiera Hannah Arendt (1950).

\section{Un PENSAMIENTO de LA APARIENCIA}

La política, señala Arendt (1978), no es una sustancia ni una categoría, sino un "pensamiento de la apariencia" que metafóricamente se encarna en los rostros particulares para recordarnos de que los pueblos, las comunidades, no son nunca abstracciones sino cuerpos que hablan y actúan. La multiplicidad con la que cada comunidad se identifica comporta gestos, movimientos y deseos únicos. La diferencia nos recuerda que la construcción social es una apariencia de diversidades, y son los espacios intermedios entre individuos, los intervalos, lo que permite pensar la comunidad como un juego recíproco, una red de intercambio de intervalos que conecta las diferencias entre sujetos, como ha mostrado toda una iconografía cinematográfica heredera y consciente de la tradición del retrato burgués, con Pier Paolo Pasolini, con Chantal Akerman o, sobre todo, con Aleksandr Sokurov. Precisamente, en una de sus últimas películas, Francofonia (2016), alude abiertamente a esta cuestión al señalar: "La primera vez que vi el Louvre, quedé atrapado por esas caras. Es el pueblo, el pueblo. Las personas tal y como querría verlas. Los entiendo. Pertenecen a su época, pero los reconozco. Franceses, un pueblo europeo. Me pregunto que habría sido de la cultura europea sin el arte del retrato".

Acompañando a esas palabras, la cámara recorre en un suave movimiento retratos renacentistas surgidos del taller de Corneille de Lyon y otros pintores franceses y holandeses. "¿Quién hubiera sido si no hubiera podido ver los ojos de los que vivieron antes de mí?", se pregunta Sokurov. Como el propio Warburg, el cineasta va tejiendo un gran panel de rostros al calor de una pregunta $\dot{\imath} Q u e ́$ es ser europeo? $\dot{\partial}$ De qué modo se representa a un 
pueblo?, pues en ambos casos, Sokurov y Warburg, desean saber cómo los artistas del pasado imaginaron tanto su tiempo como la experiencia visual anterior. Además, Sokurov parece compartir con Hannah Arendt la mencionada noción de espacio político, como diferencias y espacio entre rostros. La obsesión que preside el sistema de rankings en Nosedive es, por el contrario, la homogeneización, el limado de diferencias, multiplicidades e intervalos, que Lacie descubrirá justo a continuación. Durante el viaje que le lleva hasta la boda de su amiga Naomi para realizar un discurso como dama de honor que le permita incrementar su puntuación, el azar confronta a Lacie con una serie de situaciones que le hacen ir descendiendo en la escala social. Su encuentro con Susan, una camionera que le explica el desmoronamiento de su ranking después de que los hospitales rechazasen tratar el cáncer de su marido por no alcanzar la calificación requerida, constituye, en ese sentido, un preludio de su llegada a la boda, ebria y desharrapada.

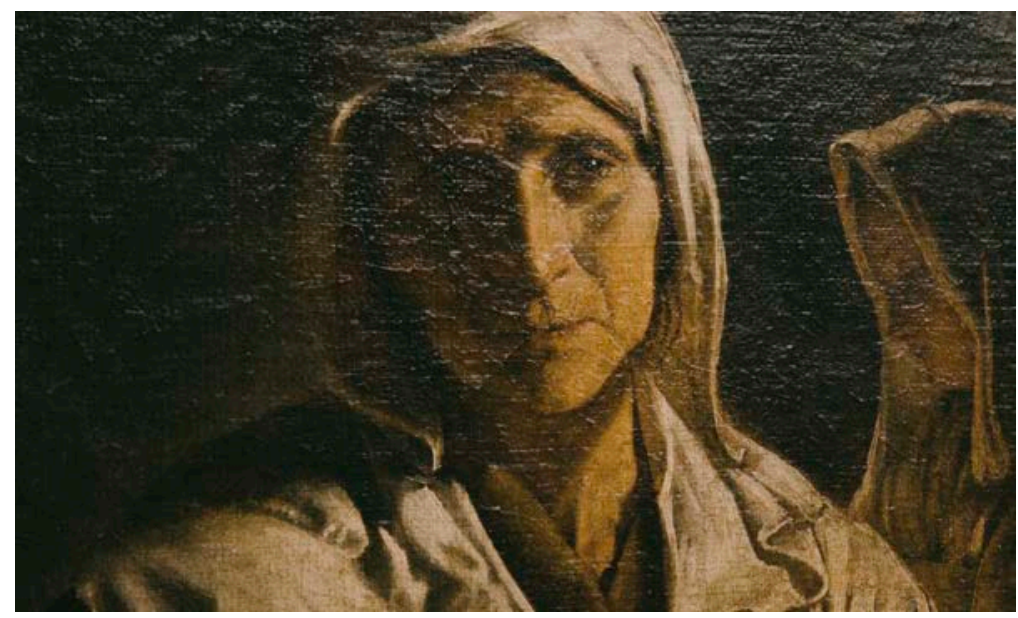

Fig.- 4. Aleksandr Sokurov, Francofonia (2017).

Sin embargo, donde el capítulo pone al descubierto la pobreza de negatividad de las sociedades contemporáneas y su desbordamiento a través de la espita de la ficción (Pintor, 2018) es al final, con Lacie en un calabozo, sin hardware de calificación y dedicándose a cruzar insultos con un hombre encerrado en la celda contigua, en una catarsis de hostilidad que supone un alivio tras la ausencia de alteridad que sustenta la construcción gestual del capítulo. Frente a la dominante de luz blanca y las superficies definidas que todo el capítulo ha exhibido, la penumbra, las rejas y los ros- 
tros descompuestos, encendidos, mal peinados y atravesados por muecas de desprecio invocan formas del realismo tanto pictórico como un tipo de crudeza de la piel en el que los códigos parecen estar más cerca de Bacon, Lucian Freud u otros pintores de la Escuela de Londres que del sistemático vaciado de las imágenes cuasi-publicitarias que han acompañado a Lacie durante todo el capítulo. Si, quizá el argumento que sustenta la colección iconográfica de imágenes anteriores, pudiera ser, sobre un panel warburgiano, el ascenso social, la publicidad y, en última instancia, el capital como motor abstracto de una formalización gestual, en el último momento del capítulo, con la rabia, cristaliza un verdadero pathosformeln.

La confusión constante entre trabajo y un ocio que ha sido colonizado por la dialéctica del rendimiento, atraviesa el conjunto de los capítulos de Black Mirror, si bien en algunos casos apunta hacia la presencia distópica tradicional de un Gran Otro, un Gran hermano que controla los hilos, como en el caso de 15 Million Merits (\#1×02), donde la población trabaja pedaleando sobre una bicicleta para acumular "méritos", una moneda digital que cierra el ciclo de adquisición de los productos virtuales anunciados mientras pedalean. El tribunal de jueces del reality show Hot Shot donde Abi (Jessica Brown) participa constituye la viva encarnación de ese poder en la sombra. Sin embargo, Nosedive expone, como The Entire History of You (\#1×03) y Hang the DJ (\#4x04) la aceptación colectiva de una serie de fórmulas consensuadas que prolongan una sociedad post-foucaultiana donde la vigilancia se ha expandido en una multiplicidad de agentes que coincide con la totalidad de individuos de la sociedad. Nosedive responde con habilidad a la pregunta ¿̇Cómo dar cuerpo iconográfico a una sociedad de la auto-explotación consensuada? ¿En qué formas gestuales hacerla cristalizar?

La sociedad disciplinaria que describe Foucault, ${ }^{13}$ todavía regida por el no y la prohibición, no sólo ha ido dando lugar a una sociedad del control ${ }^{14}$

13 "La "discipline" ne peut s'identifier ni avec une institution ni avec un appareil; elle est un type de pouvoir, une modalité pour l'exercer, comportant tout un ensemble d'instruments, de techniques, de procédés, de niveaux d'application, de cibles ; elle est une "physique" ou une "anatomie" du pouvoir, une technologie", señala Foucault, en Surveiller et punir (1975: 251).

14 La expresión se refiere a una sociedad en la que el control de las personas tiene lugar "non plus par enfermement, mais par contrôle continu et communication instantanée", señala Deleuze (1990), y en la que "les mécanismes de maîtrise se font [...] toujours plus immanents au champ social, diffusés dans le cerveau et le corps de citoyens" (Negri-Hardt 2000: 48). Se trata de una expresión de atribución polémica, que Deleuze afirmó haber tomado de la obra del escritor William Burroughs y desarrollada tanto por el propio Deleuze, como por Negri y Hard o Razac (2008). 


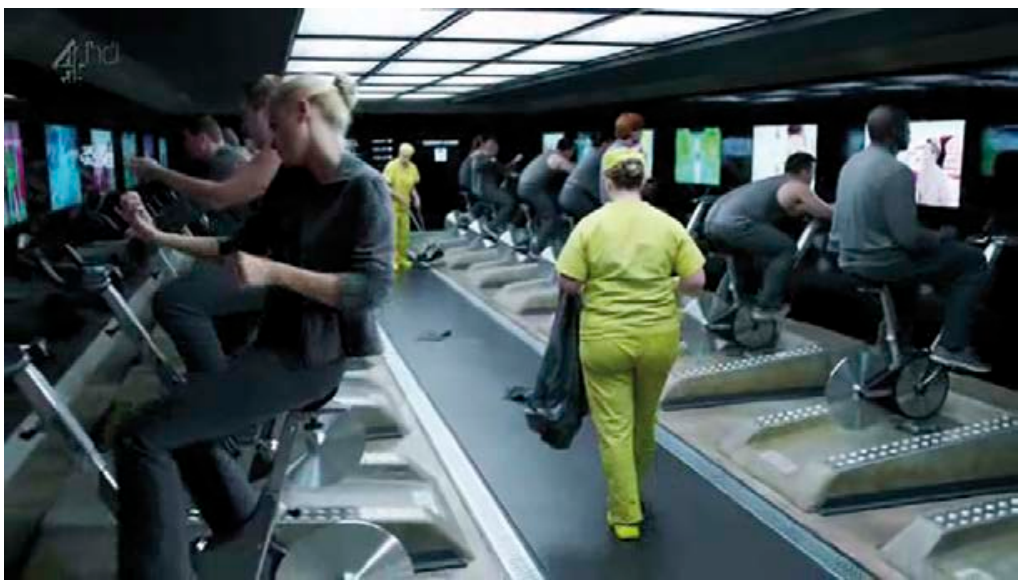

Fig.- 5. Black Mirror, 15 Million Merits (\# 1x02).

sino también al desarrollo complementario de una sociedad del rendimiento, cuyos individuos no son sujetos de obediencia sino emprendedores de si mismos. La sociedad disciplinaria, tal como aparece descrita por Foucault, es una sociedad de la negatividad fundada en el mandato y la prohibición, conforme al verbo modal negativo "no-poder" (Nicht-Dürfen). Por el contario, la sociedad del rendimiento que define Byung-Chul Han "se caracteriza por el verbo modal positivo poder (können) sin límites. A la sociedad disciplinaria todavía la rige el no. Su negatividad genera locos y criminales. La sociedad del rendimiento, por el contrario, produce depresivos y fracasados" (2012: 27). En los rostros sonrientes acompañados de un ranking que rodean a Lacie, en la denegación del espacio político que supone la multitud de avatares de la masa atomizada ${ }^{15}$ que contempla Hot Shot desde sus cubículos en 15 Million Merits, cristaliza una positividad que resulta mucho más terrorífica que la negatividad foucaultiana del deber: el imperativo de la pura responsabilidad sobre uno mismo, ajeno a cualquier forma de pacto social.

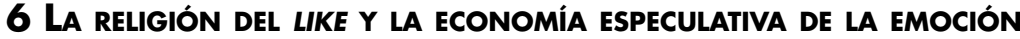

El lamento del individuo depresivo "Nada es posible", sólo se explica porque el valor central que se fomenta es el opuesto: "Nada es imposible". La necesidad de sostener la propia identidad (Ehrenberg 2008) en un hori-

15 Entendida, con Paolo Virno (2002), como una negación de la auténtica dimensión activa, política y fundada en la diferencia de la multitud. 
zonte marcado por la promesa de poder ser cualquier cosa resulta agotadora para personajes que constituyen una parodia de las formas de vida post-capitalistas, tal como el sistema de atribución de pareja de Hang the $D J$ pone de manifiesto. No es casual que uno de los protagonistas del especial White Christmas (2016) de Black Mirror esté encarnado por el actor Jon Hamm, cuya interpretación de Don Draper en Mad Men (AMC: 20072015) da forma a una de las grandes figuras melancólicas de la serialidad contemporánea, entregado a la obsesión por encarnar todos los gestos del éxito y la felicidad programada (Pintor, 2015). Don no sólo decide usurpar la personalidad del verdadero Don Draper, fallecido por accidente en la Guerra de Corea, sino que resuelve entregarse a un simulacro mayor, el de ser feliz y sostener con su hogar la viva imagen del sueño americano -"Yes we can", es el lema que alcanza el presente desde la construcción social de la realidad que eclosiona en los años cincuenta- a pesar incluso de sí mismo y de las fisuras de un sistema fuera del cual no puede pensar. Pero ya no se trata tan sólo de que, como señala Han, el animal laborans se auto-explote a sí mismo, sino que trabajo y ocio coinciden en una actividad única y sin fin, que corresponde, de acuerdo con la premisa de Walter Benjamin (1985: 100-104), con una actividad cultual. Esto es, frente al mencionado motivo del otium clásico, el capitalismo no encarna solamente, como ha estudiado Max Weber (2003), una secularización de la fe protestante, sino que es per se un fenómeno religioso desarrollado a partir del cristianismo. El consumo, como culto ineludible del capitalismo, constituye una celebración perenne, que no reconoce laborables y festivos ni persigue expiación alguna. Lejos de aspirar a la redención, la devoción cultual del capitalismo empuja al sujeto hacia la culpa y la anomia, hacia la fatiga de la multi-estimulación y el destino de un "cansancio que separa" (Handke, 2006). La dictadura del like y el miedo a la exclusión social abordados en Nosedive y 15 Million Merits constituyen, asimismo un fenómeno económico-religioso estructurado en un bucle capaz de engullir la energía política colectiva y, asimismo, de anular los gestos singulares de resistencia hacia el sistema.

Siguiendo a Giorgio Agamben (2017: 113-132) y su interpretación del estudioso de la ciencia de las religiones David Flüsser, la paradoja del capitalismo es que el culto se ha emancipado del objeto, de modo que el capitalismo cree sólo en el puro hecho de creer, en el crédito o, lo que es lo mismo, el dinero. La fe entendida, a través de la Epístola a los hebreos del apóstol Pablo como "sustancia de cosas esperadas", ha sido incorporada por la esfera del dinero, que se ha adueñado de manera plena del futuro. Sin embargo, el mérito principal de Black Mirror no estriba sólo en mostrar, a través de tramas tan oscuras como las de Crocodile (\#4x03), 
una sociedad cuya religión es el crédito. $\mathrm{Ni}$ siquiera es ilustrar la tesis de Guy Debord (1967) según la cual el capitalismo, en su fase extrema, se presenta como una pura acumulación abstracta de imágenes, en la cual el dinero, como el lenguaje, han perdido toda vinculación con las cosas y lo único que se comunica es la propia comunicabilidad, la dimensión fática del crédito. En capítulos como The Entire History of You (\#1x03), Hang the DJ (\#4x04) o San Junipero (\#3x04), Black Mirror apunta hacia una fase ulterior en la que la habilidad del capitalismo para hacer de la comunicabilidad abstracta el centro de una religión escatológica de la que la Creación y el Juicio Final han sido desalojados, se adueña de un último reducto del capital: la pura transmisibilidad de la emoción, que pasa a ser su capital simbólico.

¿Qué gestos son entonces los que configuran el escenario de la pérdida de libertad en las sociedades del control y el rendimiento abordadas por Black Mirror? ¿En qué pathos u omisiones de fórmulas gestuales cristaliza su minuciosa aproximación a la distopía? Paradójicamente, y en el contexto del concepto de Gestell, esto es el dispositivo, paradigma o la "matriz disciplicinar"16 propia de la tecnología, formulado por Heidegger en su Die Technik und die Kehre (1962) ${ }^{17}$ lo que llama la atención es, como ya se ha ido constatando, el desplazamiento desde el bagaje iconográfico tradicional asociado a la distopía hacia una iconografía en positivo del sueño americano, que a menudo se quiebra más a través de giros narrativos que iconográficos. $\mathrm{Si}$, por una parte, es posible afirmar una eventual supervivencia visual de elementos asociados a la ciencia ficción cinematográfica distópica, como las multitudes, las grandes pantallas, los uniformes, las ruinas y páramos asolados y los interiores de aspecto clínico (Pintor, 2012), los lineamientos dominantes sobre los que se despliega Black Mirror son otros, y se pueden organizar en torno a tres ejes fundamentales, que podrían plasmarse en otros tantos paneles o fórmulas de montaje siguiendo el modelo del atlas visual Mnemosyne, de Aby Warburg.

16 Thomas S. Kuhn (1962) utiliza los términos "paradigma" y "matriz disciplinar" al referirse a lo que Foucault $(1966,1969)$ denominaría "dispositivos". Desarrolla asimismo, una noción fundamental en el contexto del estudio de las formas de pensar en relación con la representación de la tecnología en Black Mirror: el concepto de Denkstil, o estilo de pensamiento en Fleck.

17 Tanto Gianni Vattimo (1985) como Giorgio Agamben (2006) abordan el desarrollo de la noción heideggeriana de Gestell como dispositivo y paradigma en relación a Foucault. "Quando Heidegger, in Die Technik und die Kehre (La tecnica e la svolta), scrive che Ge-stell, significa comunemente "apparato" (Gerät), ma che egli intende con questo termine, il raccogliersi di quel (dis) porre [Stellen), che (dis)pone dell'vomo, cioè esige da lui lo svelamento del reale sul modo dell'ordinare (Bestellen)", la prossimità di que- sto termine con la dispositio dei teologi e con i dispositivi di Foucault è evidente" (Agamben 2006: 19). 
Por una parte, al hacer énfasis en el control, un gran número de capítulos muestra la articulación de los mecanismos biopolíticos (Foucault 1975, 2001 a y b, 2004) de las sociedades contemporáneas a través de gestos alegóricos como el mencionado pedaleo y la vigilancia constante a través del panóptico benthamiano, o la compleja relación con implantes de memoria como el de The Entire History of You y la "máscara" que impide a los soldados ver con su auténtico aspecto a los inmigrantes que masacran conforme al programa eugenésico de Men Against Fire (\#3×05) - nuevamente, la denegación del gesto real-. En Arkangel (\#4×02) el Gestell tecnológico pone en manos de una madre la posibilidad de bloquear los estímulos cargados de negatividad que pueden llegar al cerebro de su hija gracias a un implante controlado desde una Tablet $y$, de igual modo, en una de las historias que vertebran White Christmas, los miembros de una pareja pueden bloquearse, desoírse, anular por consiguiente toda transmisión pática y gestual y conseguir una orden estatal de alejamiento ante cualquier desacuerdo. Si en The Handmaid's Tale (Hulu: 2017-2018) la imagen de las amas sujetando a las criadas fértiles mientras el cónyuge las penetra para inseminarlas condensa en un solo icono pregnante el programa biopolítico de la serie, y Children of Men (Alfonso Cuarón 2006) halla ese icono en el embarazo milagroso, Black Mirror fabrica una pluralidad de imágenes de la intervención sobre los cuerpos de la población, fundada sobre todo en el gadget.

Por otra parte, un segundo lineamiento, o panel warburgiano corresponde al salto entre la biopolítica y la psicopolítica fomentado por la dictadura de la transparencia (Vattimo 1989, Han B-Ch. 2013). En el salto que media entre el simulacro de The Truman Show (Peter Weir, 1988) y la intervención sobre la subjetividad explorada en películas como Strange Days (Kathryn Bigelow 1995), Minority Report (Steven Spielberg 2002) y muchas de las ficciones surgidas del influjo de Philip K. Dick, el universo digital que resulta de la convergencia entre redes sociales y realidad virtual se convierte en un instrumento de control social capaz de colonizar, replicar e intervenir sobre la mente y el libre albedrío. Quizá por eso uno de los temas más repetidos es el de la humillación, ya sea política - The National Anthem, The Waldo Moment (\#2x03), Hated in the Nation (\#3x06) - , ya personal - The Entire History of You, Shut Up and Dance (\#3x03) - en un mundo de post-privacy en el que los recuerdos se vuelven engramas ${ }^{18}$ perennemente accesibles.

18 Término que aparece en el capítulo Crocodile (\#4×03) y que también emplea en su teoría Aby Warburg, pues inspira la noción de huella mnémica, dinamograma -dynamogramm-, que le permite estudiar la supervivencia de las fórmulas de pathos de la pintura antigua, en la teoría de los engramas de Selon Semon y las huellas formales - formgepräge- de Antón Springer (Gombrich, 1995). 
El gesto de rebelión del protagonista de The Entire History of You extrayéndose su implante de memoria, de la niña de Arkangel rompiendo la Tablet contra una madre cuyo dolor no puede ver por efecto del software de enmascaramiento o del protagonista de 15 Million Merits amenazando con quitarse la vida con un fragmento de vidrio tienen su continuidad en los verdaderos pathos engendrados por la posteridad digital.
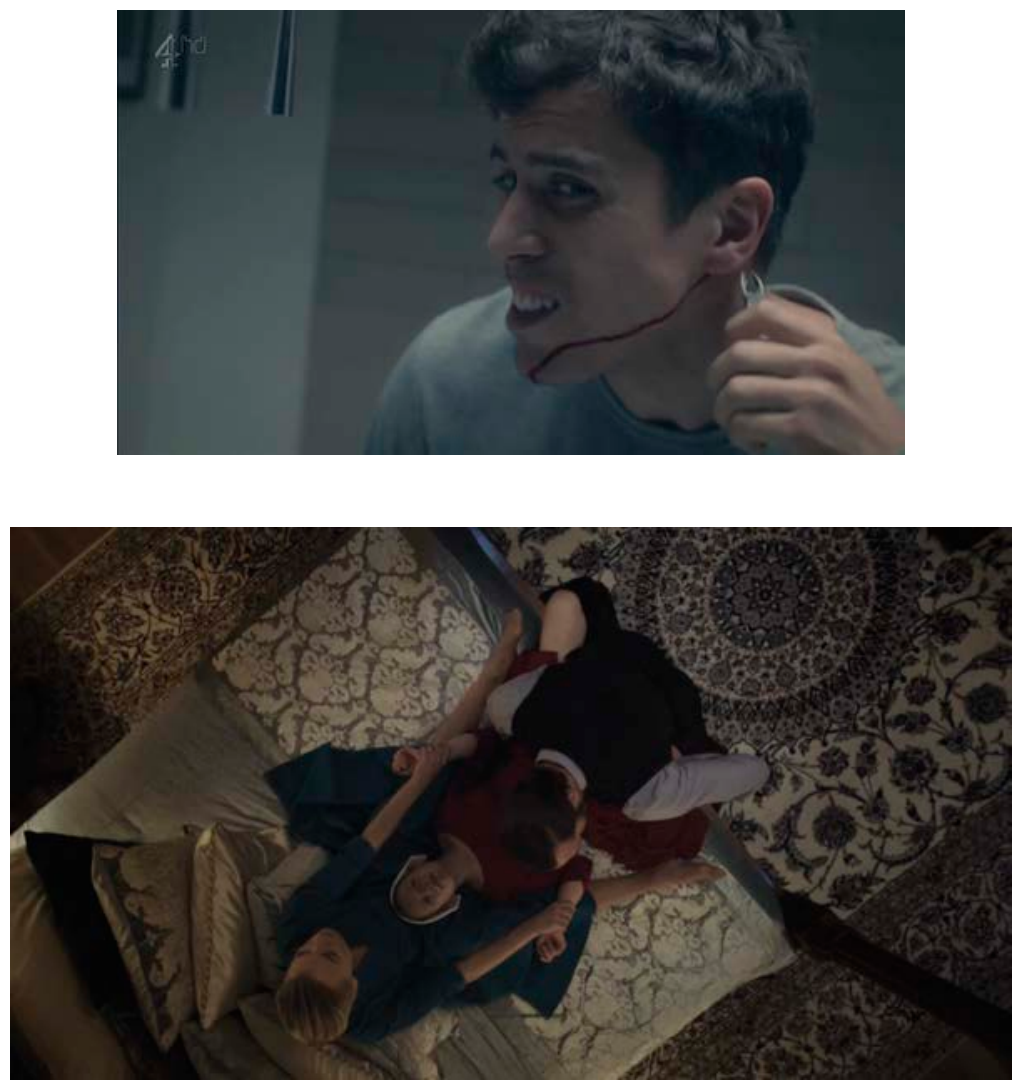

Figs.- 6 y 7. Black Mirror, The Entire History of You (\#1×03) y The Handmaid's Tale (Hulu: 2017-2018) 


\section{UNA POSTERIDAD DIGITAL}

Desalojar una conciencia de su cuerpo y encarnarla en un objeto o en la nube a través de la digitalización es uno de los nudos narrativos que Black Mirror muestra con mayor frecuencia, de modo que a la dimensión cultual del post-capitalismo de las imágenes y las emociones se suma la construcción de un infierno digital fundado en la eterna repetición de unos mismo gestos, en continuidad con el pathos de los contrapasos del Infierno de Dante (Pintor, 2019). Junto a la réplica digital de la conciencia de una mujer en una de las historias de White Christmas, y el trasvase de la conciencia de la esposa fallecida en un peluche en Black Museum (\#4x06) es, sobre todo, en este mismo capítulo la eterna ejecución en la silla eléctrica del avatar holográfico de un condenado la que encarna un pathos de dolor pictórico clásico, heredero de Caravaggio, Bacon y Munch, con un resultado plástico asimismo semejante al de las investigaciones fisiológicas de Duchenne de Boulogne (1862), que simulaba expresiones emocionales en el sujeto aplicando choques eléctricos a los músculos faciales.

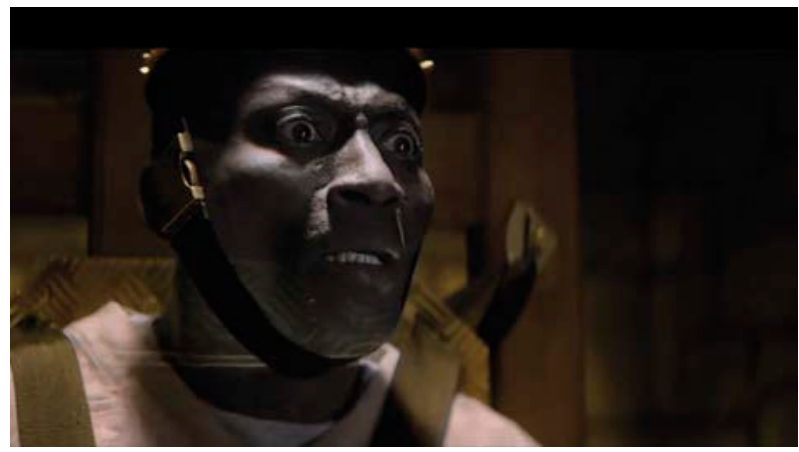

Fig.- 8. Black Mirror, Black Museum (\#4x06)

Sin embargo, la posteridad mencionada alumbra también el tercer lineamiento gestual: el de los gestos de la felicidad que ocupan la primera parte de Nosedive o, sobre todo, San Junipero, donde ancianos y moribundos pueden verter su conciencia en un software donde seguir viviendo en un cuerpo joven y en su época preferida. Al ritmo de la canción Heaven Is a Place on Earth de Belinda Carlisle, la historia de amor de Yorkie y Kelly contrapone los pathos de una juventud feliz - la danza, el beso, el enamoramiento junto al mar - con lo que Deleuze denominó la penultimidad. Las imágenes finales del capítulo, con el viaje final de las dos jóvenes en coche, una vez Kelly ha decidido librarse a la eternidad del software que, desde 2040, les permite seguir viviendo en 1987, contrastan con la secuencia que muestra los servidores donde unos brazos mecánicos van 
cargando los discos duros en los que se encuentra esa experiencia emocional. $\mathrm{Si}$, por una parte, las imágenes apelan a un pathos de entrega tan destructivo como de entera felicidad amorosa que constituye un claro homenaje a la secuencia final de Thelma y Lovise (Ridley Scott, 1991), así como todo un cine de los ochenta, por otra, nos habla de la imposibilidad gestual impuesta por la tecnología.

En efecto, el contraste entre la intensidad de un pathos amoroso fundado en el melodrama clásico y la inexpresividad chata, llana, de los discos duros podría constituir, en muchos sentidos, y desde una perspectiva de aproximación histórico-psicológico-gestual, la cifra del trabajo de Charlie Brooker en Black Mirror. En su texto El exhausto (2015), Deleuze se refiere a la penultimidad como la aproximación demorada a un final siempre diferido. La escatología post-capitalista, que sustituye el final de los tiempos cristianos por un tiempo del final expandido aparece explicada en el encadenamiento de imágenes de vertido digital, eutanasia y pathos concretos de la felicidad en este capítulo. A través del concepto síntoma cultural, que Ernst Cassirer utilizó en su antropología filosófica para referirse a aquellas manifestaciones culturales que encarnaban un cierto sentir del tiempo, y que en muchos sentidos posee una fuerte afinidad con el propósito de Warburg de construir una "ciencia de la cultura", es posible entender que en esas secuencias de San Junipero cristaliza el síntoma cultural de una penultimidad deleuziana bajo la cual se entiende nuestra sociedad contemporánea. De igual modo que Warburg, que insistía en trabajar a través de la repolarización de las imágenes, en métodos contrastantes y de re-contextualización, es interesante pensar qué imagen podría constituir tanto la explicación como la antítesis de esa articulación, de ese montaje que liga la felicidad de Yorkie y Kelly con un la forma ortogonal de un disco duro. Acaso el extraordinario capítulo final de la serie Mad Men (\#7x07, Waterloo) pueda brindar la imagen que haga emerger la verdadera dimensión de esas secuencias de imágenes y sus implicaciones iconográfico-gestuales. A la imagen de Don Draper haciendo yoga en una pequeña comuna, en un entorno idílico, y sobre la recitación del mantra "Aum", el capítulo monta sin solución de continuidad el anuncio Hilltop (1971), de Coca-Cola, la más perfecta plasmación del concepto de positividad en la sociedad del rendimiento - It's the real thing, cantan jóvenes de todas las razas en una negación escatológica de diferencias, multiplicidades y un verdadero espacio político-. Es frente a ese canto, también irónico, a los pathosformeln del capitalismo, que final de San Junipero contrapone la negatividad inexpresada de los discos duros con unos gestos, unas fórmulas de pathos, cuyo significado primario, el libre albedrío, aparece completamente invertido en una clara advertencia sobre las potencialidades narrativas de la tecnología. 

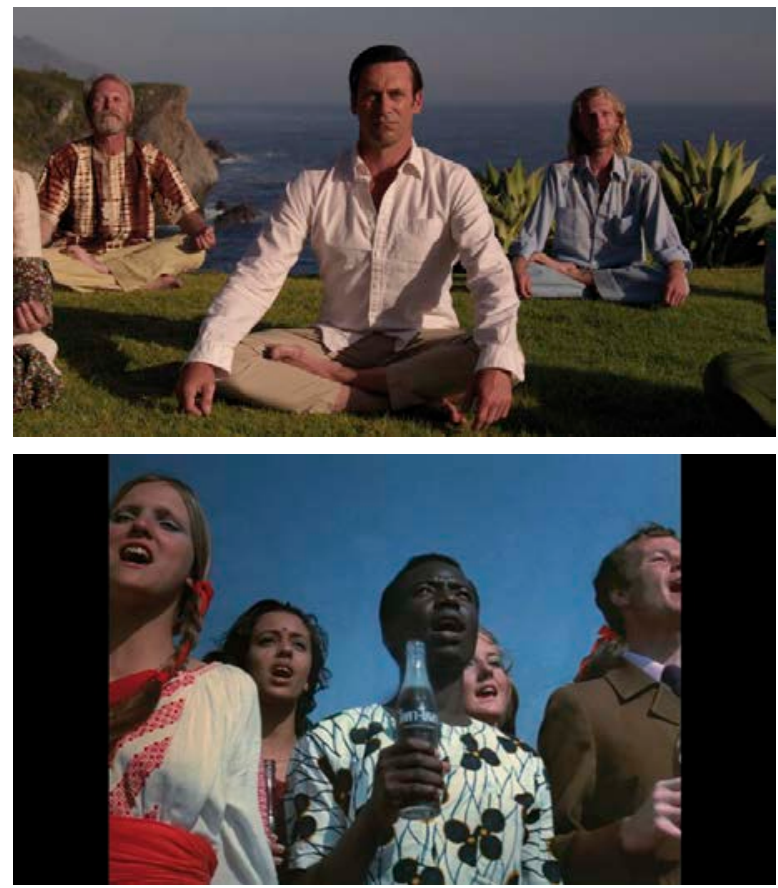

Figs.- 9a y 9b. Black Mirror, San Junípero (\#3×04).
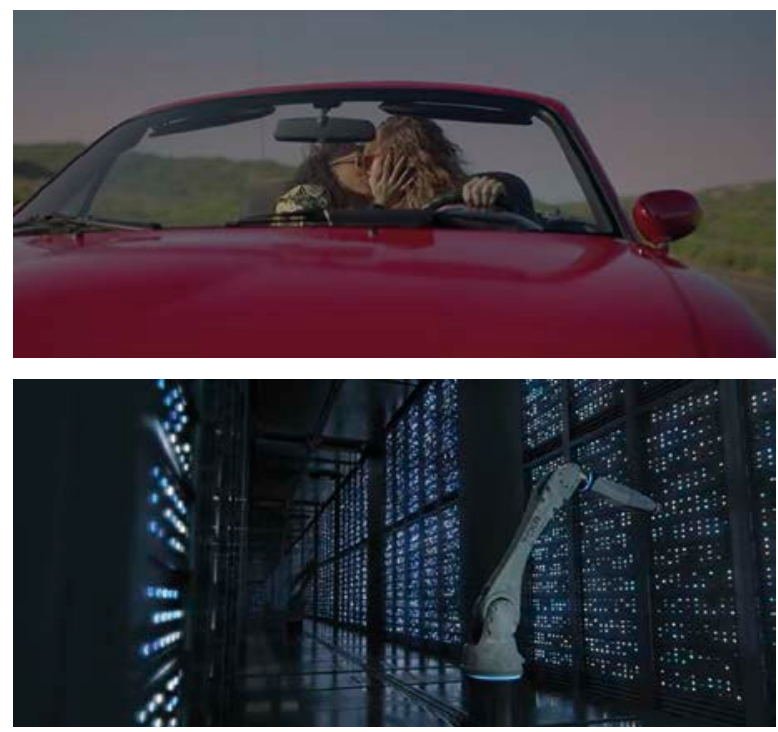

Figs.- 10a y 10b. Mad Men Waterloo (\#7×07). 


\section{Bibliografía}

AGAMBEN, Giorgio (1980), "Vocazione e voce", en AGAMBEN, Giorgio, La potenza del pensiero, Neri Pozza, Vicenza, pp. 77-90.

AGAMBEN, Giorgio (1982), II linguaggio e la morte. Un seminario sul luogo della negatività, Einaudi, Turín.

AGAMBEN, Giorgio. (2001), "Notas sobre el gesto", en AGAMBEN, Giorgio, Medios sin fin. Notas sobre la política, Pre-textos, Valencia.

AGAMBEN, Giorgio (2005), "Aby Warburg e la scienza senza nome", en La Potenza del pensiero, Neri Pozza, Vicenza, pp. 123-146.

AGAMBEN, Giorgio (2006), Che cosa è un dispositivo?, Nottetempo, Roma.

ARENDT, Hannah (1950), "Was ist Politik". En: Arendt, Hannah (1993). Was ist Politik. 24. Fragmente Aus dem Nachlaß, Munich.

ARENDT, Hannah (1958), The Human Condition. The University of Chicago [(2005), La condición humana, Paidós, Barcelona].

ARENDT, Hannah (1978), Vom Leben des Geistes. I. Das Denken. I. Das Wollen. Munich [(1979). The Life of the Mind. The Groundbreaking Investigation on How We Think, New York, 1979].

BAINES, John (1989), "Communication and display: the integration of early Egyptian art and writing", Antiquity n 63 (240), pp. 471-482.

BAUDRILLARD, Jean. (2006), "Violencia de la imagen. Violencia contra la imagen", en BAUDRILLARD, Jean, La agonía del poder, Círiculo de Bellas Artes, Madrid.

BENJAMIN, Walter. (1985), Kapitalismus als Religion, en BENJAMIN, Walter Gesammelte Schriften, vol, VI, Suhrkamp, Frankfurt, pp. 100-104.

BONIFACCIO, Giovanni, giureconsulto. (1616), L'Arte de'Cenni. Vicenza. https://archive.org/details/lartedecenniconl02boni

BULGAKOVA, Oksana (2005), Fabrika zhestov, Novoe Literaturnoe Obozrenie, Moscow.

BULGAKOVA, Oksana (2013), "La fábrica cinematográfica de gestos. Imágenes y memoria del cuerpo en la era de la globalización" en BENAVENTE, Fran y SALVADÓ, Gloria (eds.) Poéticas del gesto en el cine europeo contemporáneo, Intermedio, Barcelona.

CHARE, Nicholas. WATKINS, Liz (2015), "Screen Signs: Cultures of Gesture in Cinema", Journal for Cultural Research n ${ }^{\circ} 19$ (1).

CHASTEL, André (2004), El gesto en el arte, Siruela, Madrid.

CHOMSKY, Noam, HERMAN, Edward (1988), Manufacturing Consent: The Political Economy of the Mass Media, Pantheon, Nueva York. 
CIRLOT, Victoria (2017), "Zwischenraum/Denkraum: oscilaciones terminológicas en las Introducciones al Atlas de Aby Warburg (1929) y Ernst Gombrich (1937)", Engramma. La tradizione classica nella memoria occidentale, $\mathrm{n}^{\circ} 150$.

DARWIN, Charles (1872), The Expression of the Emotions in Man and Animals, John Murray, London.

DEBORD, Guy (1967), La Societé du spectacle, Buchet/Chastel, París.

DELEUZE, Gilles (1990), "Post-scriptum sur les sociétés de contrôle", en: Deleuze. G. Pourparlers 1972 - 1990. París, Les éditions de Minuit.

DELEUZE, Gilles (2004), Foucault, Minuit, París.

DELEUZE, Gilles (2015), L'esausto. A cura di Ginevra Bompiani, con un testo di Giorgio Agamben, Nottetempo, Roma.

DIDI-HUBERMAN, Georges (2002), L'Image survlvánte. Histoire de l'art et temps des fantômes selon Aby Warburg, Minuit, Paris.

DIDI-HUBERMAN, Georges (2009), "Atlas ou le gai savoir inquiet." In L'Oeil de l'histoire, 3, Minuit, Paris.

DIDI-HUBERMAN, Georges (2009), "Quand les images prennent position." In L'Oeil de l'histoire, 1, Minuit, Paris.

DIDI-HUBERMAN, Georges (2010), "Remontages du temps subi." In L'Oeil de l'histoire, 2, Minuit, Paris.

DIDI-HUBERMAN, Georges (2012), "Peuples exposés, peuples figurants." In L'Oeil de l'histoire, 4, Minuit, Paris.

DIDI-HUBERMAN, Georges (2016), Peuples en Armes, Peuples en Larmes. L'Oeil de l'Histoire, 6, Minuit, Paris.

DUCHENNE DE BOULOGNE, Guillaume (1862), Mécanisme de la physionomie humaine ou anlyse électro-physiologique de l'expression des passions, Renouard, Paris.

EHRENBERG, Alain (2008), La fatigue d'être soi-même. Depression et Société, Odile Jacob, París.

FOUCAULT, Michel (1966), Les Mots et les choses. Une archéologie des sciences humaines, Gallimard, París.

FOUCAULT, Michel (1969), L'Archéologie du savoir, Gallimard, París.

FOUCAULT, Michel (1975), Surveiller et punir, Gallimard, París.

FOUCAULT, Michel $\left(2001^{\circ}\right)$, "La naissance de la médecine sociale", en: Dits et écrits, t. 2, Gallimard, París, pp. 207-228.

FOUCAULT, Michel (2001 b), "L'incorporation de I'hôpital dans la technologie moderne", en: Dits et écrits, t. 2, Gallimard, París, pp. 508-521. 
FOUCAULT, Marc (2004), Naissance de la biopolitique, Cours au collège de France 1978-1979, Hautes études, Gallimard-Seuill, París.

FUMAROLI, Marc (2008), L'Ecole du silence: Le sentiment des images au XVlle siècle, Flammarion, París.

FUMAROLI, Michel (2010), París-Nueva York-París. Viaje al mundo de las artes y de las imágenes. Diario de 2007 a 2008, Acantilado, Barcelona. GOMBRICH, Ernst H. (1995), Aby Warburg, una biografía intelectual, Alianza Forma, Madrid.

GUZZO, Pietro Giovanni y BONIFACIO, Giovanna. (ed.), Otium Ludens. Stabiae, cuore de l'impero romano, Castellammare di Stabia, Longobardi, 2009.

HAN, Byung-Chul. (2012), La sociedad del cansancio, Herder, Barcelona. HAN, Byung-Chul. (2013), La sociedad de la transparencia, Herder, Barcelona.

HANDKE, Peter (2006), Ensayo sobre el cansancio, Alianza, Madrid.

HEGEL, Georg Wilhem (1970), Encyclopédie des sciences philosophiques, I. La Science de la logique (1827-1830), Vrin, Paris.

HEIDEGGER, Martin (1927), Sein und Zeit, Max Niemeyer, Halle.

HEIDEGGER, Martin (1962), Die Technik und die Kehre, Neske, Pfullingen. JASPERS, Karl (1928), Psychopathologie générale (1913-1922), Alcan, París.

KUHN, Thomas S. (1962), The Structure of Scientific Revolutions, Chicago University Press, Chicago.

LAMPRECHT, Karl (1900), Die kulturhistorische Methode, Gaertner, Berlin. LAMPRECHT, Karl (1906-11), Deutsche Geschichte. Zwölf Bände in neunzehn Büchern, Hermann Heyfelder \& Weidmannsche Buchhandlung, Berlin LENK, Sabine y KESSLER, Frank (1996), "Cinéma d'attractions et gestualité" en GILI, Marie y LAGNY, Pinel (eds.) Les vingt premières années du Cinéma français, AFRHC/Sorbonne Nouvelle, París.

MANTEGAZZA, Paolo (1874), Dell'espressione del dolore, Parte I, in Società Italiana di Antropologia e Etnologia (a cura di), Archivio per l'Antropologia e la Etnologia, vol. IV, pp. 4-11. http://www.antropologiaetnologia.it/node/17

MANTEGAZZA, Paolo (1874), Fisiologia del Piacere, G., Bernardoni tipografo-editore, Milano.

MANTEGAZZA, Paolo (1876), Atlante del dolore. Fotografie prese dal vero e da molte opere d'arte che illustrano gli studi sperimentali sull'espres- 
sione del dolore del dottore Paolo Mantegazza, Giacomo Broggi fotografo editore, Firenze.

MANTEGAZZA, Paolo (1880), Fisiologia del Dolore, Fratelli Dumolard, Milano.

MANTEGAZZA, Paolo (1881), Fisionomia e Mimica. Milano, Fratelli Dumolard, Milano.

MANTEGAZZA, Paolo (1874), Fisiologia del Piacere, G. Milano, Bernardoni tipografo-editore

MANTEGAZZA, Paolo (1876), Dell'espressione del dolore, Parte II, in Società Italiana di Antropologia e Etnologia (a cura di), Archivio per l'Antropologia e la Etnologia, vol. Vl, , pp. 1-16. http://www.antropologiaetnologia.it/node/17

MANTEGAZZA, Paolo (1880), Fisiologia del Dolore, Fratelli Dumolard, Milano.

MANTEGAZZA, Paolo (1881), Fisionomia e Mimica, Fratelli Dumolard, Milano.

MERLEAU-PONTY, Maurice (1945), Phénoménologie de la perception, Gallimard, París.

MICHAUD, Philippe-Alain (1998), Aby Warburg et l'image en mouvement. Suivi de Souvenirs d'un voyage en pays Pueblo (1923) et Project de voyage en Amérique (1927), Macula, Paris.

MURANO, Jessica (2016), Fisiologia del gesto. Fonti warburghiane del concetto di Pathosformel, Aisthesis, anno IX, n 1 , pp. 153-175.

NEGRI, Antonio, HARDT, Michael (2000), Empire, Exils, París

NIETZSCHE, F. (1872), Die Geburt der Tragödie aus dem Geiste der Musik. Leipzig: E. W. Friedritzsch.

NIETZSCHE, Friedrich (1977), Fragments posthumes (1869-1872), Gallimard, Paris.

PEARSON, Roberta (1992), Eloquent Gestures. The Transformation of Performance Style in The Griffith Biograph Films, University of California Press, Berkeley.

PINTOR, Iván (2017), "Silence and Fog. On Gesture, Time, and Historicity in the Films of Aleksandr Sokurov", Mise en geste. Studies of Gesture in Cinema and Art, special issue of Apparatus. Film, Media and Digital Cultures in Central and Eastern Europe 5.

PINTOR, Iván (2018b), "O Somma Luce. Otherwordly journeys and encounters with the Goddess. A comparative approach of the Dantean heritage in the comic books of Hugo Pratt, Fellini and Manara and Makyo", Dante e l'Arte, Vol. V. 
PINTOR, Iván (2009), Melancholy and Sacrifice in Contemporary Science Fiction, Formats, Journal of Audiovisual Communication, vol.V.

PINTOR, Iván (2012), "This is the end. La melancolía y el apocalipsis en la ciencia ficción", TRAMA Y FONDO, $n^{\circ} 31$, Asociación Cultural Trama \& Fondo, Segovia, pp. 123-139.

PINTOR, Iván (2015), "Nunca volveremos a casa: la figuración del hogar en Mad Men". En: VV.AA. Mad Men o la frágil belleza de los sueños en Madison Avenue. Madrid, Errata Naturae (pp. 107, 133).

PINTOR, Iván (2017), Formas del Atlas y el Ensayo Visual a Partir de Aby Warburg: el Montaje, la Emoción y el Gesto. Barcelona, Research, Art, Creation, 5(2), 156-188. doi: 10.17583/brac.2017.2684.

PINTOR, Iván (2018), "El vacío, la cólera y el mal en la ficción serial contemporánea. Una estética de la negatividad" en HUERTA FLORIANO, Miguel Ángel y SANGRO COLÓN Pedro (ed.), La estética televisiva en las series contemporáneas, Editorial Tirant Lo Blanch, Valencia.

RAZAC, Olivier (2008), Avec Foucault, après Foucault. Disséquer la société de contrôle, L'Harmmattan, París.

SARTRE, Jean-Paul. (1938), Esquisse d'une théorie des émotions, Hermann, París.

SHAW, lan; NICHOLSON, Paul (1995), The Dictionary of Ancient Egypt, Harry N. Abrams, Inc., Nueva York, p. 197.

SLOTERDIJK, Peter (1998), Sphären I. Blasen, Mikrosphärologie, Suhrkamp, Frankfurt.

SLOTERDIJK, Peter (1999), Sphären II. Globen, Makrosphärologie, Suhrkamp, Frankfurt.

SLOTERDIJK, Peter (2004), Sphären III. Schäume, Plurale Sphärologie, Suhrkamp, Frankfurt.

VÄLIAHO, Pasi (2010), Mapping the Moving Image. Gesture, Thought and Cinema Circa 1900. Amsterdam University Press, Amsterdam.

VATTIMO, Gianni (1985), Poesia e ontologia, Ugo Mursia editore, Milán.

VATTIMO, Gianni (1989), La societá trasparente, Garzanti, Milán.

VIRNO, P. (2002), Grammatica della moltitudine. Per una analisi delle forme di vita contemporanee, Derive/Approdi, Roma.

WARBURG, Aby (2016), Mnemosyne. Einleitung. Introduzione al Bilderatlas [1929], nuova edizione critica e traduzione di Maurizio Ghelardi, "La Rivista di Engramma" n. 138, settembre/ottobre.

WARBURG, Aby (1995), Images from the region of the Pueblo Indians of North America, Ithaca, Nueva York. 
WARBURG, Aby (1999), "Sandro Botticelli's Birth of Venus and Spring. An examination of Concepts of Antiquity in the Italian Early Renaissance" en The Renewal of pagan antiquity: contributions to the cultural history of the European Renaissance, Los Angeles.

WARBURG, Aby (1999), La rinascita del paganesimo antico. Contributi alla storia della culura, La nuova Italia, Florencia.

WARBURG, Aby (1988), Schlangenritual. Ein Reisebericht [Bilder aus dem Gebiet der Pueblo-Indianer in Nord-Amerika, Vortrag gehalten am 21 april 1923, Kreuzlingen], Mit einem Nachwort von U. Raulff, Verlag Klaus Wagenbach, Berlín.

WEBER, Max (2003), La ética protestante y el espíritu del capitalismo, Fondo de Cultura Económica, México D.F.

WUNDT, Wilhelm (1912), Elemente der Völkerpsychologie: Grundlinien einer psychologischen Entwicklungsgeschichte der Menschheit, Leipzig. 